\title{
MICROANALYSIS AND SOURCE APPORTIONMENT OF PARTICULATE EMISSIONS FROM ANTHROPOGENIC SOURCES IN TWO INDIAN CITIES
}

\author{
SARAGUR MADANAYAK SHIVA NAGENDRA ${ }^{1}$, ANJU ELIZBATH PETER ${ }^{1}$, \\ JYOTHI S. MENON ${ }^{1} \&$ AVINASH BALACHANDRA AKOLKAR ${ }^{2}$ \\ ${ }^{1}$ Department of Civil Engineering, Indian Institute of Technology Madras, India \\ ${ }^{2}$ Central Pollution Control Board, Ministry of Environment, Forest and Climate Change, Delhi, India
}

\begin{abstract}
The morphological and elemental characteristics of ambient particulate matter (PM) collected at two contrasting Indian cities were investigated. Single particle analysis by scanning electron microscopy combined with energy dispersive spectroscopy was carried out on the PM collected at residential, commercial and industrial sites in Delhi and Chennai cities during winter and monsoon seasons. The more diversity in morphological and elemental composition of PM in Delhi city was observed as compared to Chennai city revealed the complexity in source characteristics. The trans-boundary pollution sources were also found to be a major contributor in Delhi city. Mineral particles with a mixed origin of crustal and anthropogenic sources were identified as most abundant species in ambient air, irrespective of types of sampling locations. Even though combustion borne particles were found to be dominant in both the cities, their characteristics were entirely different. The meteorological conditions were also having a profound influence on particle morphology. Source apportionment of PM by UNMIX model indicated that biomass burning and coal combustion (30\%) and re-suspension of traffic induced crustal elements (19\%) to be the dominant source contributors in Delhi. Vehicular emissions and sea salt spray $(30 \%)$, biomass and garbage burning $(20 \%)$ were the identified potential source contributors to PM in Chennai. The present study indicated that source-based abatement strategies will be helpful to abate the present particulate pollution faced by Indian cities.

Keywords: particulate matter, microanalysis, particle morphology, elemental composition, source apportionment.
\end{abstract}

\section{INTRODUCTION}

Source apportionment with comprehensive investigation of $\mathrm{PM}_{2.5}$ emissions from different sources is of utmost importance for air quality research in order to understand its wider impacts on climate change, radioactive forcing, public health and welfare. Indian mega cities are experiencing episodes of elevated particulate matter (PM) concentration [1], often violating the National Ambient Air Quality Standards (NAAQS). Considering the health perspective, $\mathrm{PM}_{2.5}$ may be more toxic as it can carry heavy metals, sulfates and other hazardous compounds into lungs and respiratory tracts [2]. Dey et al. [3] reported that $51 \%$ of Indian subcontinent's population (1.4 billion people) are being exposed to continuing rise in $\mathrm{PM}_{2.5}$ concentration that surpasses the World Health Organization's (WHO) annual air quality threshold of $10 \mu \mathrm{g} / \mathrm{m}^{3}$.

The past source apportionment studies in India showed that vehicular emission and traffic congestion [1], fuel adulteration, industrial emissions, coal combustion, biomass and fuel wood burning [4] are potential sources of $\mathrm{PM}_{2.5}$. The blending of kerosene, heavier fuel oils and spent waste solvents into automotive fuels such as gasoline and diesel increased the sulfur content and density of adulterated fuels. The use of higher density and sulfur content of adulterated fuels results in emission of higher PM concentration and smoke [5], [6]. Past studies also indicated the consistent increase of $\mathrm{PM}_{2.5}$ concentrations in the ambient air of Delhi city [4]. It was observed that the industrial pollution which was once the major 
contributor (56\% in 1970-1971) in Delhi has declined considerably (20\% in 2006) in the recent years [7]. But the contribution from the transportation sector increased exponentially in Delhi in recent years [8]. Even after the implementation of several mitigation policies such as shifting of fuel from diesel to compressed natural gas (CNG), transforming coal power plants to natural gas [1] and restriction on entry of heavy duty diesel vehicles [9], urban air pollution still remains a major policy challenge in megacities like Delhi. For instance, the recent implementation of odd-even car trial scheme reduced traffic congestion however, it remains unclear as for its effectiveness in bringing down the PM concentration to acceptable NAAQS limits. It is even recommended that before such a trial is implemented, a complete source apportionment of the PM is required to strengthen mitigation measures [8]. A similar scenario was observed in Chennai city with exception of its coastal location which helps in the dispersion of pollutants. The monitoring studies conducted in various industrial and traffic sites in Chennai city indicated that the PM concentrations exceeded the NAAQS [10], [11]. Srimuruganandam and Shiva Nagendra [10] reported that $88 \%$ of PM emissions in heavy traffic roads are contributed by diesel exhaust emissions. In India, a few compendious studies on the morphological characteristics of $\mathrm{PM}_{2.5}$ and elemental compositions were carried out in urban areas of Delhi [12], Varanasi [13]; high Himalayas [14]; Agra [15], indoor environments of Delhi and Chennai [16], [17].

Previous studies focused mostly on the relationship between sources of pollution and $\mathrm{PM}_{2.5}$ characteristics, however, the morphological characteristics had been less explored. The influence of considerable differences in topography and meteorological parameters on shape, size and composition of $\mathrm{PM}_{2.5}$ has not been studied so far. In the present study, we have investigated the morphological and elemental characteristics of ambient $\mathrm{PM}_{2.5}$ collected at residential, commercial and industrial area of two contrasting Indian mega cities.

\section{MATERIALS AND METHODS}

\subsection{Study area descriptions}

Under National Ambient Air Quality Monitoring (NAAQM) network, central pollution control board (CPCB) is carrying out ambient air quality monitoring in several cities in India including Delhi and Chennai. Fig. 1(a) shows the six monitoring stations established under NAAQM in various parts of Delhi representing residential (Pitampura, Janakpuri and Siri Fort), commercial (Nizamuddin) and industrial areas (Shahzada Bagh and Shahdara). The two NAAQM network considered in Chennai city were Anna Nagar and Adyar (Fig. 1(b)). Adyar is located in south Chennai and has several schools and colleges and residential areas. Anna Nagar is located in the north-western part of Chennai and has mixed land use.

\subsection{Meteorological characteristics of Delhi and Chennai}

The climate of Delhi has been categorized into four major seasons across the year: winter (December-February), summer (March-May), monsoon (June-August) and post-monsoon (September-November). Delhi has an extreme climate with chilling winter, torrid summer and moderate rainfall. In summer season, the city experiences dry climate with the temperature reaching up to $48^{\circ} \mathrm{C}$. In the monsoon season, Delhi city receives more than $80 \%$ of the total annual rainfall. The occurrence of frequent ground-based inversion conditions with low temperatures going down to $4^{\circ} \mathrm{C}$ were observed during winter season. Delhi, being an inland territory, is incapable to dilute its air pollution compared to other metropolitan cities including Kolkata, Mumbai and Chennai which can abate the ambient air pollution by using 


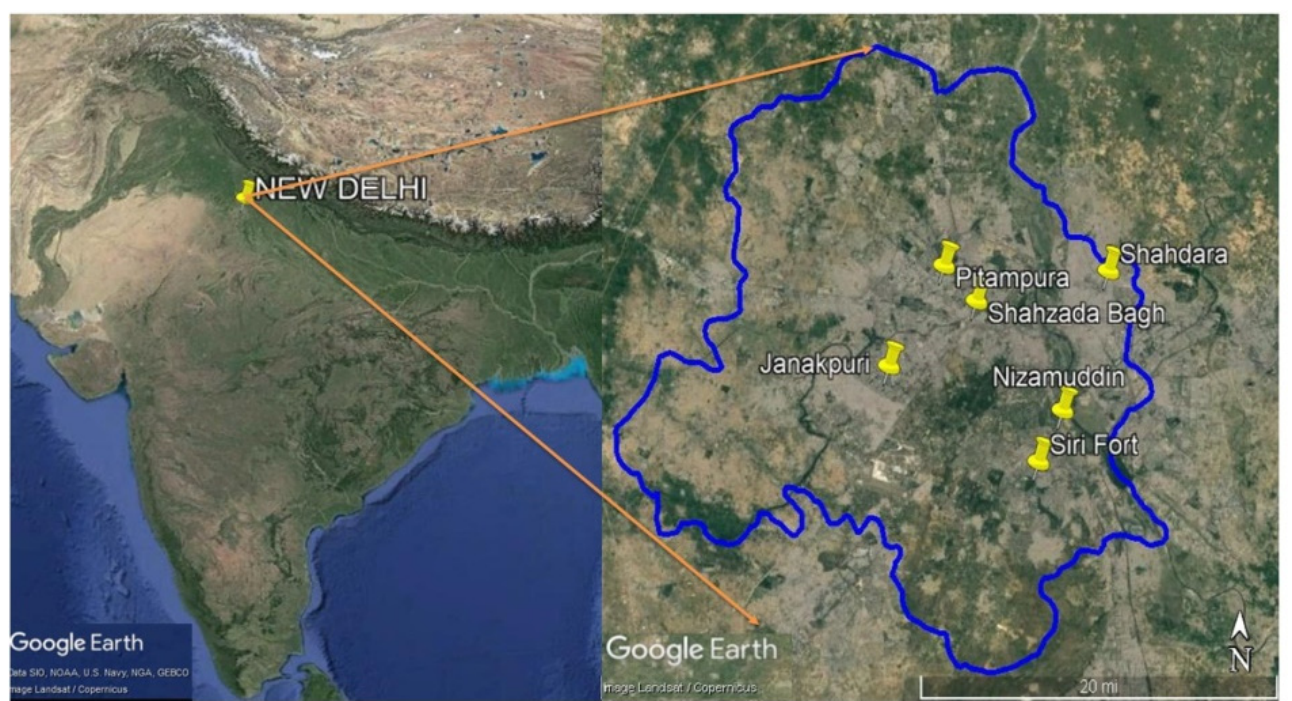

(a)

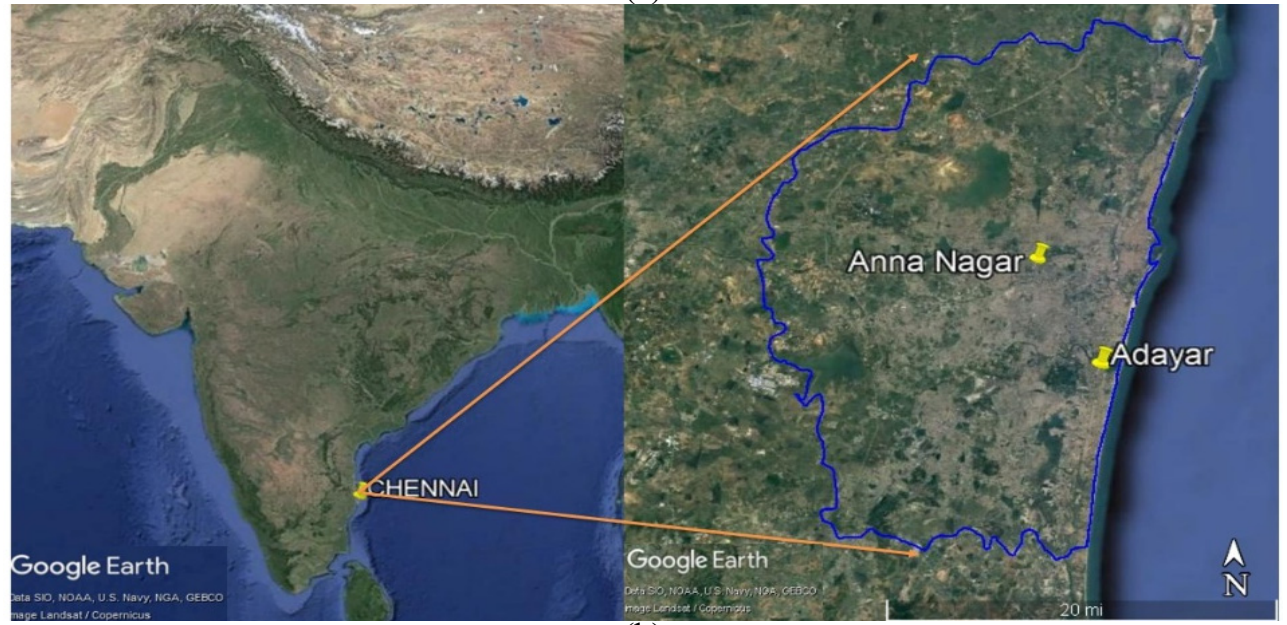

(b)

Figure 1: (a) Monitoring locations at Delhi; (b) Monitoring locations at Chennai.

the moderating effects of sea. Delhi represents a great variability in the seasonal patterns although is surrounded by the regions of varied climate such as Thar desert of Rajasthan, Himalayan hilly regions and Indo-Gangetic plains.

Chennai has a humid, dry and wet climate and is closely located southern coastal part of India and influenced by onshore and land breeze phenomena. The climate of Chennai has been categorized into winter (January-February), summer (March-May), north-east monsoon (June-September) and south-west monsoon (October-December). Chennai receives considerable amount of rainfall during south-west monsoon because of sea-breeze induced convections. Predominant winds in Chennai are usually southwesterly between April and October and north-easterly during the rest of the year. 


\section{$2.3 \mathrm{PM}_{2.5}$ sampling}

A fine volume (16.7 L/min) sampler (APM 550, Envirotech Instruments Pvt. Ltd., India) was used for 24-hour sampling of $\mathrm{PM}_{2.5}$. $\mathrm{PM}_{2.5}$ samples were collected on PTFE filters (46.2 mm dia; $2 \mu \mathrm{m}$ pore size) with polypropylene ring (Whatman International Limited, USA).Before and after sampling, PTFE filters were kept for conditioning in the desiccator, gravimetric mass was determined using an analytical microbalance (Sartorius, ME5-F) with $1 \mu \mathrm{g}$ readability.

\subsection{Morphological and chemical characterization of $\mathrm{PM}_{2.5}$}

Scanning electron microscopy combined with energy dispersive spectroscopy (SEM-EDS) was used for microanalysis of collected $\mathrm{PM}_{2.5}$ samples. Half of particle laden filters were cut into small pieces of $1 \mathrm{~cm}^{2}$. The small filter paper pieces were smoothly pasted on a double side carbon adhesive tape which was mounted onto aluminum stubs. The stubs were gold coated to achieve conductivity and vacuum durability using sputter coater (Cresington sputter coater 108). Then the coated stubs were placed in vacuum chamber of SEM. SEM images have been collected by using secondary electron detector with an accelerating voltage of $20-30 \mathrm{kV}$. The working distance was kept $10 \mathrm{~mm}$ during analysis. FEI Quanta 200 SEM operates in the high vacuum mode ( 0.07 torr). An x-ray spectrum of selected SEM image has been collected for 50 seconds at the rate between 900-2000 counts $\mathrm{S}^{-1}$. Carbon, oxygen and fluorine were considered as the background substrate of PTFE filter paper.

\subsection{Multivariate analysis}

UNMIX is a multivariate receptor model which derives the source number by means of reducing data space dimensionality through the singular value decomposition (SVD) method. UNMIX uses self-modeling curve resolution to check that the results follow the non-negative constraints on source compositions and contributions.

\section{RESULTS}

\subsection{Air quality in Delhi and Chennai}

Table 1 summarizes the $\mathrm{PM}_{2.5}$ mass concentration measured over different seasons in Delhi and Chennai respectively. The analysis of air quality data of Delhi indicated that during winter, maximum $\mathrm{PM}_{2.5}$ mass concentration of $177 \mu \mathrm{g} / \mathrm{m}^{3}$ was observed at Pitampura (residential site) and minimum concentration of $32 \mu \mathrm{g} / \mathrm{m}^{3}$ was observed at Nizamuddin (commercial site). During monsoon the maximum concentration of $54 \mu \mathrm{g} / \mathrm{m}^{3}$ were observed at Shahdara (industrial site) and minimum concentration of $18 \mu \mathrm{g} / \mathrm{m}^{3}$ were observed at Shahzada Bagh (industrial site). The analysis of air quality data of Chennai indicated highest concentration during winter $\left(61.7 \mu \mathrm{g} / \mathrm{m}^{3}\right)$ compared to summer $\left(21 \mu \mathrm{g} / \mathrm{m}^{3}\right)$ at Anna Nagar (residential site) while it showed high concentration $\left(23.5 \mu \mathrm{g} / \mathrm{m}^{3}\right)$ at Adyar (residential site) during pre-monsoon season and lowest concentration $\left(4.3 \mu \mathrm{g} / \mathrm{m}^{3}\right)$ in post monsoon season.

\subsection{Elemental composition of $\mathrm{PM}_{2.5}$ at Delhi and Chennai in winter and monsoon seasons}

The major source contributors to elements in residential areas (Janakpuri, Pitampura and Sirifort) of Delhi city were found to be crustal soil emissions, construction activities and garbage burning. The major sources found to be contributing complex particulates in the 
Table 1: $\quad$ Summary of $\mathrm{PM}_{2.5}$ concentrations selected for SEM analysis, measured at six locations in Delhi and two locations in Chennai comprising of residential, commercial and industrial sites.

\begin{tabular}{|c|c|c|c|c|c|}
\hline \multicolumn{3}{|c|}{ Delhi } & \multicolumn{3}{|c|}{ Chennai } \\
\hline Study area & Season/month & $\begin{array}{c}\mathrm{PM}_{2.5} \\
\text { Conc. } \\
\left(\mu \mathrm{g} / \mathrm{m}^{3}\right)\end{array}$ & $\begin{array}{l}\text { Study } \\
\text { area }\end{array}$ & Season/month & $\begin{array}{c}\mathrm{PM}_{2.5} \\
\text { Conc. } \\
\left(\mu \mathrm{g} / \mathrm{m}^{3}\right)\end{array}$ \\
\hline \multirow[t]{2}{*}{ Pitampura } & Winter/February & 177 & Adyar & $\begin{array}{l}\mathrm{SW}^{*} \text { monsoon/ } \\
\text { September }\end{array}$ & 23.5 \\
\hline & Monsoon/August & 38 & & $\begin{array}{l}\text { SW monsoon/ } \\
\text { September }\end{array}$ & 4.3 \\
\hline \multirow[t]{2}{*}{ Sirifort } & Winter/January & 172 & & Winter/January & 29 \\
\hline & Monsoon/July & 44 & & Winter/January & 53 \\
\hline \multirow[t]{2}{*}{ Janakpuri } & Winter/January & 145 & $\begin{array}{l}\text { Anna } \\
\text { Nagar }\end{array}$ & $\begin{array}{l}\text { SW monsoon/ } \\
\text { September }\end{array}$ & 8.9 \\
\hline & Monsoon/August & 43 & & $\begin{array}{l}\text { SW monsoon/ } \\
\text { September }\end{array}$ & 27 \\
\hline \multirow[t]{2}{*}{ Nizamuddin } & Winter/February & 112 & & Winter/January & 37.8 \\
\hline & Monsoon/August & 32 & & Winter/January & 61.7 \\
\hline \multirow{2}{*}{$\begin{array}{c}\text { Shahzada } \\
\text { Bagh }\end{array}$} & Winter/January & 163 & & & \\
\hline & Monsoon/July & 18 & & & \\
\hline \multirow[t]{2}{*}{ Shahdara } & Winter/January & 151 & & & \\
\hline & Monsoon/July & 54 & & & \\
\hline
\end{tabular}

"South West.

ambient air of Nizamuddin (commercial area) were coal combustion, biomass burning and tire dust. The observed particles were categorized into mineral particles, syngenite, soot particles, Cl-rich particles, Fe-rich particles and Zn-rich particles. Fig. 2 shows the morphological and elemental characteristics of collected $\mathrm{PM}_{2.5}$ at Chennai during winter and monsoon. The elemental composition of observed particles indicated the occurrence of combustion activities in the study area. There are small scale industries including steel plants, toy manufacturers, rubber manufacturers, plastic manufacturing and fabrication companies are located in Shahzada Bagh and Shahdara. Based on the elemental composition of $\mathrm{PM}_{2.5}$ samples of winter season, the sources were found to be industrial emissions and combustion activities such as biomass burning and coal combustion.

The elemental composition of $\mathrm{PM}_{2.5}$ samples collected at Chennai city during winter season showed the major sources were crustal soil emissions and metal processing activities. The elemental composition of $\mathrm{PM}_{2.5}$ samples collected during monsoon season showed the presence of mineral particles (quartz), break wear particles, sea salt. Fig. 3 shows the morphological and elemental characteristics of collected $\mathrm{PM}_{2.5}$ at Chennai during winter and monsoons. 

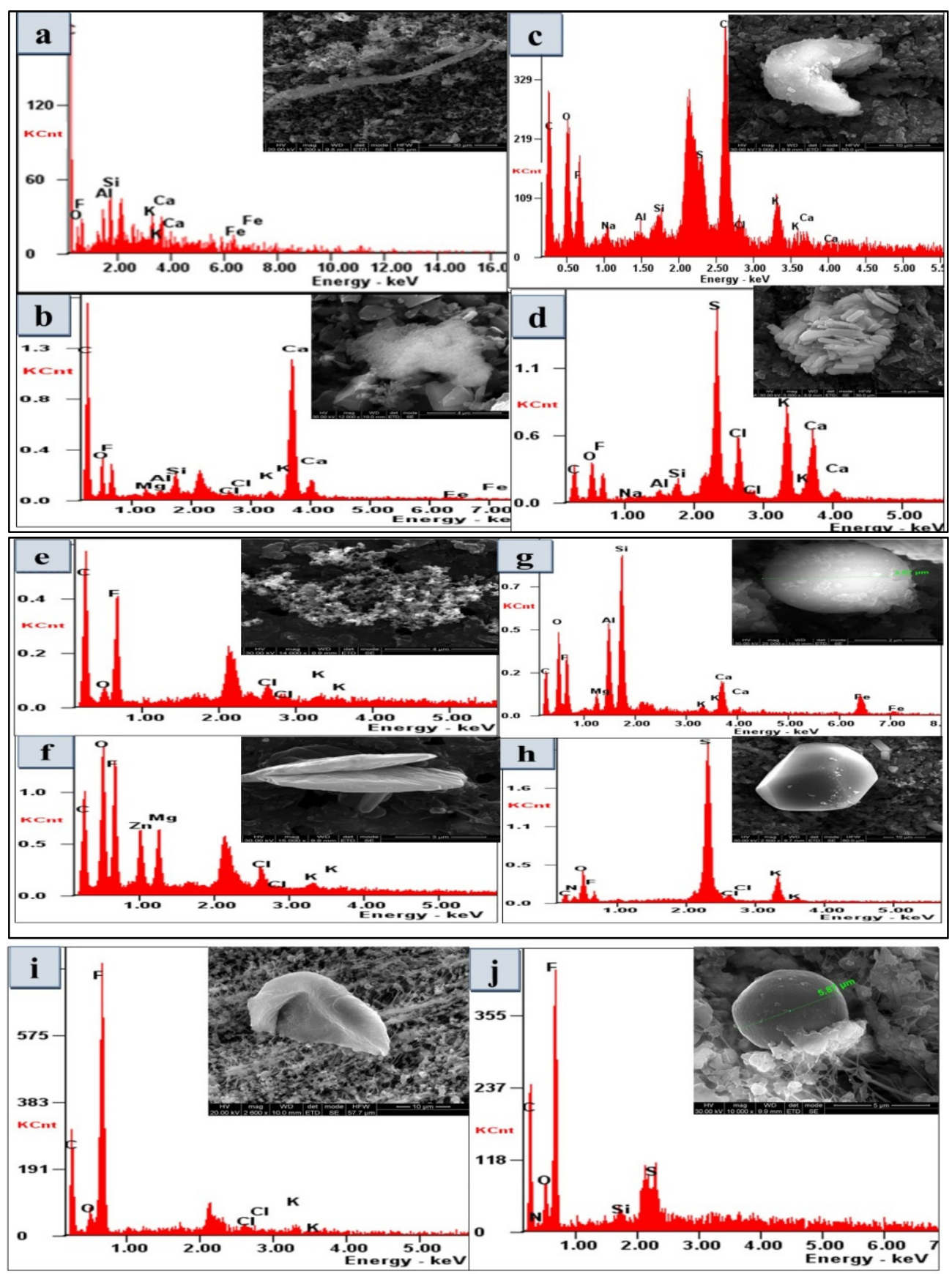

Figure 2: Morphological and elemental characteristics of collected $\mathrm{PM}_{2.5}$ at Delhi during winter and monsoon seasons. (a) Feldspar particle; (b) Ca-rich particle; (c) Cl-rich particles; (d) Syngenite particles; (e) Soot particles; (f) Zn-rich particles; (g) Fly ash; (h) Sphalerite; (i) KCl particle; (j) Tar ball. 


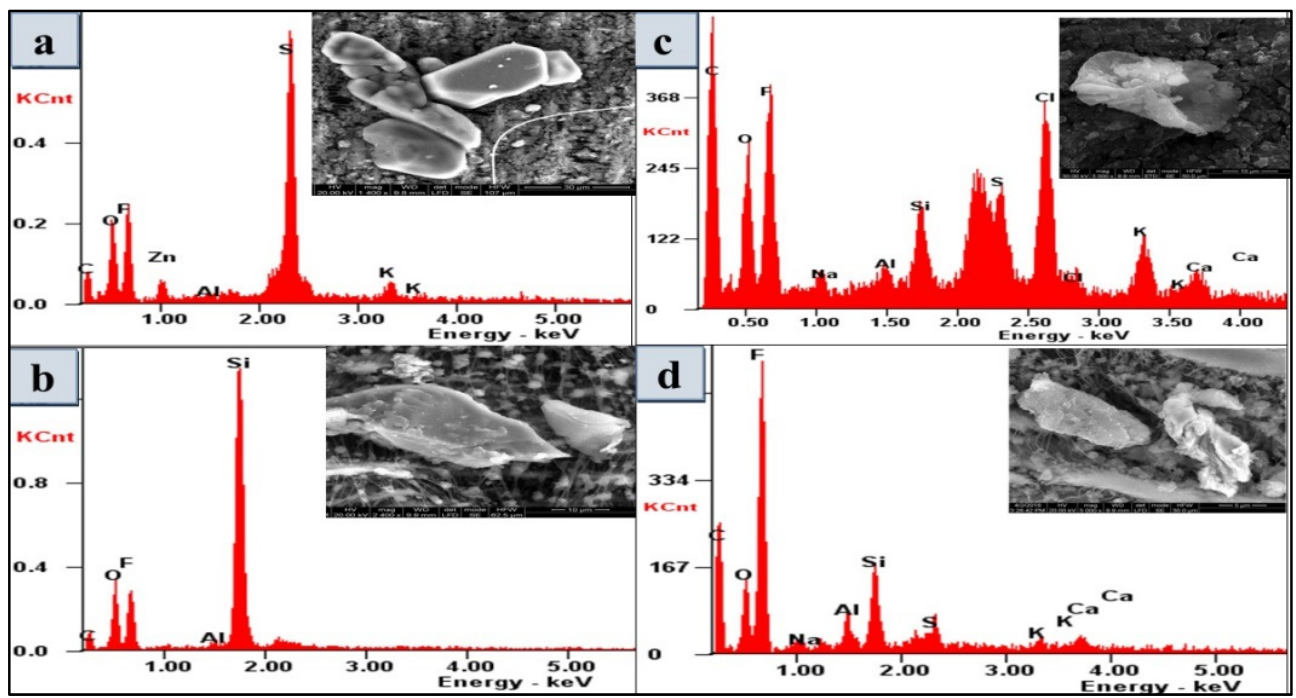

Figure 3: Morphological and elemental characteristics of collected $\mathrm{PM}_{2.5}$ at Chennai during winter and monsoon. (a) ZnS particle; (b) Quartz; (c) Sea salt; (d) Break wear particle.

\subsection{Source apportionment by UNMIX}

The source apportionment of $\mathrm{PM}_{2.5}$ by UNMIX model was carried out for Delhi and Chennai. Factor loading $>0.7$ was considered for representative species, whereas factor loading $<0.3$ was considered as poor representation. Source apportionment of $\mathrm{PM}_{2.5}$ using UNMIX model indicated that biomass burning, coal combustion and re-suspension of traffic induced crustal elements were dominant source contributors in Delhi. Whereas biomass and garbage burning, vehicular emissions and sea salt spray were identified as potential source contributors to $\mathrm{PM}_{2.5}$ in Chennai. Fig. 4 shows major source contribution to PM pollution in Delhi and Chennai, respectively.
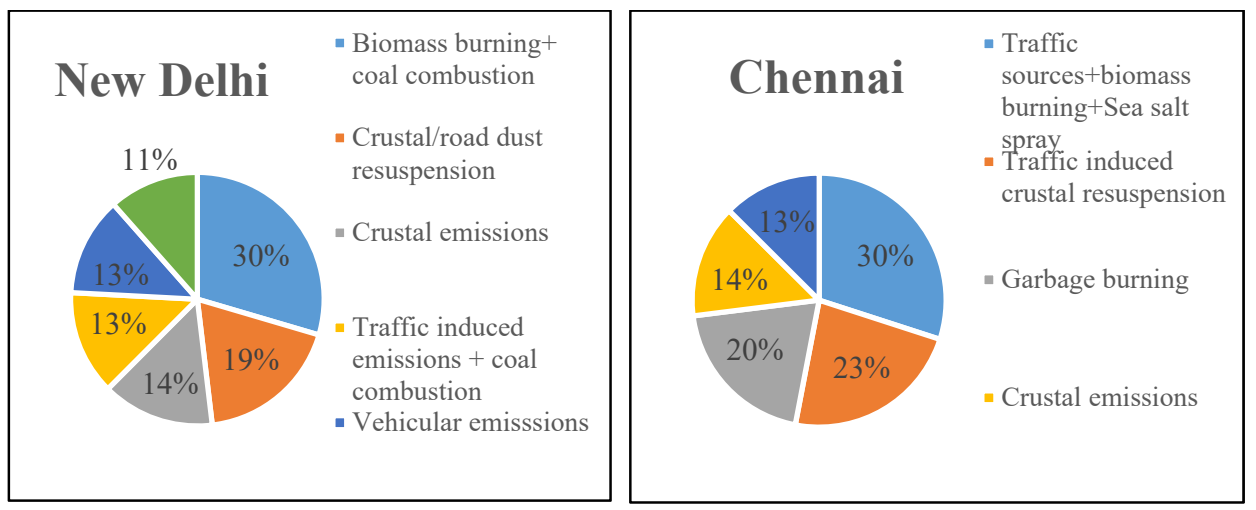

Figure 4: Source identification by UNMIX model. 


\section{DISCUSSIONS}

\subsection{Air quality at Delhi and Chennai}

High concentration of $\mathrm{PM}_{2.5}$ was observed during winter months due to the prevailing meteorological conditions including ground-based inversion with low wind conditions trapping the pollutants [18]. It was reported that burning of crop residues during winter period in Indo-Gangetic plains [19] also significantly contribute to air pollution in Delhi. Thus, air pollution in Delhi is strongly influenced by meteorological conditions as well as trans-boundary activities [18], [19]. As compared to Delhi, the PM concentration was found to be lower in Chennai city which is due to better dispersion conditions in Chennai. The major contributor to PM concentration in Chennai city was found to be traffic emissions and fugitive dust.

\subsection{Elemental composition of $\mathrm{PM}_{2.5}$ at Delhi and Chennai in winter and monsoon seasons}

The particles emitted from the crustal sources were found to be the most abundant type particles in most of the study sites. The characteristics of these particles are dependent on the geographical location in which they originate. The morphological structure of observed particles varied from regular to irregular shapes. The irregular shaped mineral particles were geologically originated while elongated and bar shaped particles were possibly formed as the result of secondary atmospheric reactions [20]. Size of geologically originated mineral particles was dominant at coarse mode whereas secondary mineral particles in fine mode. The observed particles emitted from crustal sources were composed of feldspars (Fig. 2(a)). A large quantity of respirable particles may be released during construction and demolition activities which are mostly comprised of aluminates, calcium silicates and alumino-ferrites. Ca-rich particles (Fig. 2(b)) were observed at residential areas that can be related to crustal sources, but they can also be attributed to lime production and cement industries [21]. In developing countries, garbage burning is one of the major environmental issues, commonly practiced at disposal sites, street sites and local markets to reduce waste. Most of times, garbage is being burned in proximity to residential sites or public places [22]. Garbage burning has been reported to be a major source of particulate chloride in the urban and suburban areas of Delhi city [23]. The other only plausible explanations for the higher concentration of $\mathrm{Cl}$ (Fig. 2 (c)) was observed in Pitampura due to the use of $\mathrm{Cl}$ (chlorine dioxides, chloramines etc.) as flocculating and disinfectant in water treatment and sewer plants [12]. In addition, the usage of insecticides and pesticides which contains major amount of $\mathrm{Cl}$ [12], manufacturing factories and small-scale industries were also a significant contributor to the ambient Cl. Syngenite particles (Fig. 2(d)) were the dominant species were observed in the ambient air of Nizamuddin, comprised of primarily S, K and Ca with minor amounts of $\mathrm{Cl}$. The possible sources of syngenite particles were coal combustion as well as emissions from cement industry. These particles were morphologically crystallized looking like by bar shaped structure. Similar observation was reported in the ambient air of Guiyang city, China [24]. The open field burning of agricultural crop residues after harvesting in Haryana and Punjab state also contributing to Delhi city's $\mathrm{PM}_{2.5}$ concentration [19]. The observed soot particles (Fig. 2(e)) are primarily the carbonaceous material released from the incomplete combustion of biomass. The soot aggregates observed in the present study were alike to soot particles collected by biomass burning [25]. Tire dust, which arises from abrasion between tire treads and pavement, is considered as one of primary sources of $\mathrm{Zn}$ in ambient air. Zinc oxide $(\mathrm{ZnO})$ is generally used as vulcanization accelerator which helps 
sulfur vulcanize the rubber in the tire tread [26]. Most of $\mathrm{Zn}$ in tire tread is either $\mathrm{ZnO}$ or $\mathrm{ZnS}$. The observed particles are in the form of particulate $\mathrm{ZnO}$ with an average diameter of $1 \mu \mathrm{m}$ (Fig. 2(f)). Spherical fly ash particles containing mainly $\mathrm{Si}$ and $\mathrm{Al}$ with minor concentration of $\mathrm{Ca}, \mathrm{Fe}, \mathrm{Mg}$ and $\mathrm{K}$ were observed. Fly ash particles have suave surface or coated with gypsum and other particles. Fly ash particles (Fig. 2(f)) were typically produced from coal combustion, household cooking, automobile exhaust, metallurgical plants and power plants [20], [24], [27]. Particles with higher concentration of S and Zn are classified as sphalerite ( $\mathrm{ZnS})$ (Fig. 2(g)). It is most probably emitted from the small-scale industries where $\mathrm{ZnS}$ is used as one of primary raw material for manufacturing of rubber, paper and plastic [24] which is classified as industrial minerals.

As compared to winter season there are not many variations in source contributions during monsoon seasons. In monsoon season, the observed particles were mainly mineral particles, potassium (K)-rich particle. Mostly observed mineral particles were mixed origins of crustal and anthropogenic sources. The study by Sharma and Dikshit [28] indicated that $25 \%$ of the restaurants, hotels and tandoors in Delhi city use coal and fire wood for food preparation. K$\mathrm{Cl}$ particles are present in the coal or wood were volatilized during the combustion process will be subsequently converted to particulate form through nucleation and condensation process [29]. The observed particles contain crystalline $\mathrm{K}$-salts, primarily $\mathrm{KCl}$ and irregularly shaped (Fig. 2(h)). During monsoon season, tar balls (Fig. 2(i)) were observed mainly consist of carbon (C) and oxygen (O) with minor amounts of S, K, Cl and Si [32]. The observed tar balls have spherical morphology which may be produced by heat transformation of liquid tar droplets directly emitted from biomass burning. The tar balls were also emitted by household wood combustion.

ZnS particles (Fig. 3(a)) were likely produced from a railway coach manufacturer located near the study area in Anna Nagar (Chennai) where metal processing activities have happened. Quartz particles (Fig. 3(b)) are most abundant mineral particles found at earth's surface makes its ubiquitous presence on land areas [32]. It can be introduced to atmosphere by re-suspension of street dust or PM from construction sites. Chennai is being a coastal city, sea salt particles (Fig. 3(c)) from the ocean is migrated into intercontinental polluted air and it react with gaseous $\mathrm{NOx}$ and $\mathrm{SO}_{2}$ present in humid air. Later it can be converted into completely or partially aged sea salt particles consisting of $\mathrm{NaNO}_{3}$ or $\mathrm{Na}_{2} \mathrm{SO}_{4}$ [21]. Brake wear particles (Fig. 3(d)) can be a major source of PM contributor, especially in areas where higher traffic congestion and braking frequency happens. Brake wear particle was characterized by the presence of heavy metals such as $\mathrm{Fe}, \mathrm{Cu}, \mathrm{Cr}, \mathrm{Zn}, \mathrm{Sb}, \mathrm{Sn}$ in the airborne PM concentrations [33].

\subsection{Source identification of elements in Delhi and Chennai}

The 13 species (N, Na, Mg, Al, Si, S, Cl, K, Ca, Ti, Fe, Zn, Cu) were considered in UNMIX model and 6 sources were identified in Delhi. The factor 1 was highly loaded with $\mathrm{Mg}, \mathrm{Cl}$ and $\mathrm{K}(>0.6)$ and moderately loaded with $\mathrm{S}(>0.4)$ indicated the mixed sources such as biomass burning, coal combustion and crustal emissions. $\mathrm{K}$ has been used a marker or biomass burning in previous source apportionment studies [34]. Previous source apportionment studies in Delhi have reported that biomass burning is one of major sources for PM emissions [35]. Mixed burning of cow-dung and fuel wood and burning of agricultural crop residues are considered as biomass burning sources in India [35]. Coal combustion emit a spectra of toxic elements $\mathrm{As}, \mathrm{Pb}, \mathrm{Se}, \mathrm{Zn}$ along with $\mathrm{K}, \mathrm{Cl}$ and $\mathrm{S}$ [34]. Indian coal is reported to have low sulfur content while high sulfur and ash content is detected in coal from north-eastern India. There are three coal-fired thermal power plants 
(Indraprastha, Rajghat and Badarpur) sited within city boundaries of Delhi. Banerjee et al. [35] reviewed the source apportionment studies in Delhi and reported that coal burning was one of major PM contributor in the city. Mg is emitted from crustal sources. The factor 2 was highly enriched with $\mathrm{Al}$ and $\mathrm{Si}$ indicated re-suspension of soil/crustal/road dust are often considered as major PM contributor in Indian cities [34]. The factor 3 was only enriched with $\mathrm{Na}$, which indicated crustal related emissions as $\mathrm{Na}$ was found to be as Na-feldspar (albite), abundant in earth's crust [36]. The factor 4 with high loading of $\mathrm{Ca}$ and $\mathrm{Zn}$ indicated mixed sources such as road dust re-suspension and coal burning. $\mathrm{Zn}$ is emitted from either coal burning or small-scale electroplating and galvanizing industry [37]. $\mathrm{Zn}$ is also likely to be emitted from automobile sources as it is used as fuel additive. Wear and tear of vulcanized rubber tyres on the paved road also emit $\mathrm{Zn}$ in the ambient air [38]. The factor 5 was highly loaded with $\mathrm{N}$ and moderately loaded with $\mathrm{S}$ and $\mathrm{Cu}$ indicated vehicular emissions. Vehicle fuel combustion contributed $\mathrm{N}$ and $\mathrm{S}$ in the ambient air. The $\mathrm{S}$ emissions from the Indian fuels especially diesel can be higher as the limits for sulfur under Bharat stage IV and III norms are $50 \mathrm{ppm}$ and $350 \mathrm{ppm}$, respectively. The traffic fleet is highly heterogeneous in terms of fuel, vehicle type, technology and vintage [8]. The traffic corridor in Delhi is dominated by cars and two- wheelers which runs on petroleum and diesel. $\mathrm{Cu}$ can be emitted from break wear of vehicles in traffic congested road corridor due to forced deceleration [39]. The factor 6 was only enriched with Fe indicated that Fe can be emitted either from crustal sources or burning of coal.

The 12 species ( $\mathrm{Na}, \mathrm{Mg}, \mathrm{Al}, \mathrm{Si}, \mathrm{S}, \mathrm{Cl}, \mathrm{K}, \mathrm{Ca}, \mathrm{Fe}, \mathrm{Zn}, \mathrm{Cr}, \mathrm{Ti})$ were taken into UNMIX model and 5 sources were identified. The factor 1 was highly loaded with $\mathrm{S}, \mathrm{Na}$ and $\mathrm{Zn}(>0.7)$ and moderately loaded with $\mathrm{K}, \mathrm{Cl}(>0.40)$ indicated that mixed sources such as traffic source, biomass burning and sea salt spray. Zn can be emitted from tyre-wear and two stroke engine vehicles. S can be emitted from both vehicle fuel combustion and biomass burning. Na, K, $\mathrm{Cl}$ and $\mathrm{S}$ can be emitted from sea salt spray and biomass burning. Since, Chennai city is in close proximity to Bay of Bengal, the possibility of $\mathrm{Na}, \mathrm{K}, \mathrm{Cl}$ and $\mathrm{S}$ emissions from sea salt spray can be confirmed [17]. The factor 2 was highly loaded with $\mathrm{Al}, \mathrm{Si}$ and $\mathrm{K}$ indicated crustal related emissions. Also, it can be released from re-suspension of road dust. $\mathrm{Al}$ and $\mathrm{K}$ can be emitted from fly ash fractions of diesel exhaust [34] deposited onto road corridor and re suspended along with crustal elements such as $\mathrm{Si}$. This makes the source profile as traffic induced crustal elements as a single factor. The factor 3 was highly enriched with $\mathrm{Cr}(>0.9)$ and moderately loaded with $\mathrm{Cl}$ and $\mathrm{Fe}(>0.6)$ which indicated the contributions from the garbage burning. $\mathrm{Cr}$ was considered as one of marker species for garbage burning/incineration [40]. The burning of garbage enriched with plastic waste is one of the key sources of particulate chloride in urban and sub urban environment [23]. The factor 4 was only enriched with $\mathrm{Mg}$ indicating crustal related emissions. The factor 5 was enriched with $\mathrm{Ca}$ and $\mathrm{Cl}$ which indicated the re-suspension of fly ash resulted from the garbage burning.

\section{CONCLUSION}

The PM concentrations monitored at various locations in Delhi and Chennai city were analyzed. The air quality data showed the higher levels of $\mathrm{PM}_{2.5}$ in Delhi as compared to Chennai. The microanalysis of $\mathrm{PM}_{2.5}$ indicated the presence of $\mathrm{Al}$ and $\mathrm{Si}$ in particles in higher concentrations during monsoon season as compared to winter period due to lower wind speeds and reduced re-suspension. The other particles comprised of $\mathrm{S}, \mathrm{K}, \mathrm{Ca}, \mathrm{Fe}, \mathrm{Cl}$ were observed in higher concentrations during winter and less in monsoon seasons because of wet removal of particles by rain. The morphological and elemental characterization of collected $\mathrm{PM}_{2.5}$ at different sampling locations indicated that anthropic particles were dominating at 
the study regions. The microanalysis of $\mathrm{PM}_{2.5}$ indicated the presence of mineral particles containing $\mathrm{Al}, \mathrm{Si}, \mathrm{Mg}, \mathrm{Ca}, \mathrm{Fe}$ at the residential areas with varying morphological characteristics. Commercial site (Nizamuddin, Delhi) was dominated by syngenite, mineral particle and soot particle. Similarly, the micro analysis of $\mathrm{PM}_{2.5}$ samples collected at Chennai city showed dominance of mineral particles, followed by sulfur and chlorine bearing particles in Anna Nagar. Break wear particles were dominant at Adyar site. Source apportionment of $\mathrm{PM}_{2.5}$ using UNMIX model indicated that biomass burning, coal combustion and resuspension of traffic induced crustal elements were dominant source contributors in Delhi. Whereas biomass and garbage burning, vehicular emissions and sea salt spray were identified as potential source contributors to $\mathrm{PM}_{2.5}$ in Chennai.

\section{ACKNOWLEDGEMENTS}

We would like to thank Central Pollution Control Board (CPCB) for their kind support in carrying out this research work. We are also thankful to Sophisticated Analytical Instruments Facility (SAIF), Indian Institute of Technology Madras, Chennai, India, for analyzing the samples.

\section{REFERENCES}

[1] CPCB, Air quality monitoring, emission inventory and source apportionment study for Indian cities, Central Pollution Control BoardL India, 2010.

[2] Guttikunda, S.K. \& Goel, R., Health impacts of particulate pollution in a megacityDelhi, India. Environmental Development, 6(1), pp. 8-20, 2013.

[3] Dey, S., Di Girolamo, L., van Donkelaar, A., Tripathi, S.N., Gupta, T. \& Mohan, M., Variability of outdoor fine particulate $\left(\mathrm{PM}_{2.5}\right)$ concentration in the Indian Subcontinent: A remote sensing approach. Remote Sensing of Environment, 127, pp. 153-160, 2012. DOI: http://doi.org/10.1016/j.rse.2012.08.021.

[4] Pant, P., Shukla, A., Kohl, S.D., Chow, J.C., Watson, J.G. \& Harrison, R.M., Characterization of ambient $\mathrm{PM}_{2.5}$ at a pollution hotspot in New Delhi, India and inference of sources. Atmospheric Environment, 109, pp. 178-189, 2015. DOI: http://doi.org/10.1016/j.atmosenv.2015.02.074.

[5] Kalligeros, S., Impact of using automotive Diesel fuel adulterated with heating Diesel on the performance of a stationary Diesel engine. Energy Conversion and Management, 46, pp. 677-686, 2005.

[6] UNDP and ESMAP, Catching gasoline and diesel adulteration. South Asia Urban Air Quality Management Briefing Note No. 7, 2002.

[7] Gurjar, B.R., Molina, L.T. \& Ojha, C.S.P., Air Pollution: Health and Environmental Impacts, CRC Press, 2010.

[8] Kumar, P.S., Gulia, S., Harrison, R.M. \& Khare, M., The influence of odd-even car trial on fine and coarse particles in Delhi. Environmental Pollution, 225, pp. 20-30, 2017.

[9] Gulia, S., Nagendra, S.M.S., Khare, M. \& Khanna, I., Urban air quality management: A review. Atmospheric Pollution Research, 6(2), pp. 286-304, 2015.

[10] Srimuruganandam, B. \& Shiva Nagendra, S.M., Characteristics of particulate matter and heterogeneous traffic in the urban area of India. Atmospheric Environment, 45(18), pp. 3091-3102, 2011.

[11] Jayanthi, V. \& Krishnamoorthy, R., Key airborne pollutants - Impact on human health in Manali, Chennai. Current Science, 90(3), pp. 405-413, 2006. 
[12] Srivastava, A., Jain, V.K. \& Srivastava, A., SEM-EDX analysis of various sizes aerosols in Delhi, India. Environmental Monitoring and Assessment, 150(1)-(4), pp. 405-416, 2009. DOI: http://doi.org/10.1007/s10661-008-0239-0.

[13] Singh, A.K. et al., Characterisation of Atmospheric aerosol by SEM-EDX and ion chromatography techniques for Eastern Indo-Gangetic Plain location, Varanasi, India. International Journal of Advances in Earth Sciences, 3(2), pp. 41-51, 2014.

[14] Cong, Z., Kang, S., Dong, S., Liu, X. \& Qin, D., Elemental and individual particle analysis of atmospheric aerosols from high Himalayas. Environmental Monitoring and Assessment, 160(1)-(4), pp. 323-335, 2010. DOI: http://doi.org/10.1007/s10661-0080698-3.

[15] Pachauri, T., Satsangi, A., Singla, V., Lakhani, A. \& Maharaj Kumari, K., Characteristics and sources of carbonaceous aerosols in $\mathrm{PM}_{2.5}$ during wintertime in Agra, India. Aerosol and Air Quality Research, 13(3), pp. 977-991, 2013. DOI: http://doi.org/10.4209/aaqr.2012.10.0263

[16] Srivastava, A. \& Jain, V.K., Size distribution and source identification of total suspended particulate matter and associated heavy metals in the urban atmosphere of Delhi. Chemosphere, 68(3), pp. 579-589, 2007.

[17] Chithra, V.S. \& Shiva Nagendra, S.M., Chemical and morphological characteristics of indoor and outdoor particulate matter in an urban environment. Atmospheric Environment, 77, pp. 579-587, 2013.

[18] Rizwan, S.A., Nongkynrih, B. \& Gupta, S.K., Air pollution in Delhi: its magnitude and effects on health. Indian Journal of Community Medicine: Official Publication of Indian Association of Preventive \& Social Medicine, 38(1), pp. 4-8, 2013.

[19] Sharma, A.R., Kharol, S.K., Badarinath, K.V.S. \& Singh, D., Impact of agriculture crop residue burning on atmospheric aerosol loading - A study over Punjab State, India. Annales Geophysicae, 28(2), pp. 367-379, 2010.

[20] Shi, Z. et al., Characterization of airborne individual particles collected in an urban area, a satellite city and a clean air area in Beijing, 2001. Atmospheric Environment, 37(29), pp. 4097-4108, 2003.

[21] Geng, H., Kang, S., Jung, H.J., Choël, M., Kim, H. \& Ro, C.U., Characterization of individual submicrometer aerosol particles collected in Incheon, Korea, by quantitative transmission electron microscopy energy-dispersive X-ray spectrometry. Journal of Geophysical Research Atmospheres, 115(15), pp. 1-15, 2010.

[22] Wiedinmyer, C., Yokelson, R.J. \& Gullett, B.K., Global emissions of trace gases, particulate matter, and hazardous air pollutants from open burning of domestic waste. Environmental Science and Technology, 48(16), pp. 9523-9530, 2014.

[23] Kumar, S., Aggarwal, S.G., Gupta, P.K. \& Kawamura, K., Investigation of the tracers for plastic-enriched waste burning aerosols. Atmospheric Environment, 108, pp. 4958, 2015. DOI: http://doi.org/10.1016/j.atmosenv.2015.02.066.

[24] Xie, R.K., Seip, H.M., Leinum, J.R., Winje, T. \& Xiao, J.S., Chemical characterization of individual particles (PM10) from ambient air in Guiyang City, China. Science of the Total Environment, 343(1)-(3), pp. 261-272, 2005.

[25] Li, J., Posfai, M., Hobbs, P.V. \& Buseck, P.R., Individual Aerosol Particles from Biomass Burning in Southern Africa: 2. Compositions and Aging of Inorganic Particles. Journal of Geophysical Research, 108, pp. 1-12, 2003.

[26] Adachi, K. \& Tainosho, Y., Characterization of heavy metal particles embedded in tire dust. Environment International, 30(8), pp. 1009-1017, 2004. 
[27] Gieré, R., Blackford, M. \& Smith, K., TEM study of $\mathrm{PM}_{2.5}$ emitted from coal and tire combustion in a thermal power station. Environmental Science and Technology, 40(20), pp. 6235-6240, 2006. DOI: http://doi.org/10.1021/es060423m.

[28] Sharma, M. \& Dikshit, O., Comprehensive study on air pollution and green house gases (GHGs) in Delhi. A report submitted to Government of NCT Delhi and DPCC Delhi, pp. 1-334, 2016.

[29] Zhou, K. et al., Formation and control of fine potassium-enriched particulates during coal combustion. Energy and Fuels, 24(12), pp. 6266-6274, 2010. DOI: http://doi.org/10.1021/ef101190x.

[30] Tóth, A., Hoffer, A., Nyiro-Kósa, I., Pósfai, M. \& Gelencsér, A., Atmospheric tar balls: Aged primary droplets from biomass burning? Atmospheric Chemistry and Physics, 14(13), pp. 6669-6675, 2014. DOI: http://doi.org/10.5194/acp-14-6669-2014.

[31] Pósfai, M. et al., Atmospheric tar balls: Particles from biomass and biofuel burning. Journal of Geophysical Research: Atmospheres, 109(D6), p. D06213, 2004.

[32] Xie, R.K., Seip, H.M., Liu, L. \& Zhang, D.S., Characterization of individual airborne particles in Taiyuan City, China. Air Quality, Atmosphere and Health, 2(3), pp. 123131, 2009. DOI: http://doi.org/10.1007/s11869-009-0039-x.

[33] Grigoratos, T. \& Martini, G., Brake wear particle emissions: a review. Environmental Science and Pollution Research, 22(4), pp. 2491-2504, 2015.

[34] Pant, P. \& Harrison, R.M., Critical review of receptor modelling for particulate matter: A case study of India. Atmospheric Environment, 49, pp. 1-12, 2012.

[35] Banerjee, T., Murari, V., Kumar, M. \& Raju, M.P., Source apportionment of airborne particulates through receptor modeling: Indian scenario. Atmospheric Research, 164165, pp. 67-187, 2015. DOI: http://doi.org/10.1016/j.atmosres.2015.04.017.

[36] Senthil Kumar, R. \& Rajkumar, P., Characterization of minerals in air dust particles in the state of Tamilnadu, India through FTIR, XRD and SEM analyses. Infrared Physics \& Technology, 67(13), pp. 30-41, 2014.

[37] Karar, K. \& Gupta, A.K., Source apportionment of $\mathrm{PM}_{10}$ at residential and industrial sites of an urban region of Kolkata, India. Atmospheric Research, 84(1), pp. 30-41, 2007. DOI: http://doi.org/10.1016/j.atmosres.2006.05.001.

[38] Jain, S. et al., Chemical characteristics and source apportionment of $\mathrm{PM}_{2.5}$ using PCA/APCS, UNMIX, and PMF at an urban site of Delhi, India. Environmental Science and Pollution Research, 24(17), pp. 14637-14656, 2017.

[39] Hulskotte, J.H.J., van der Gon, H.A.C.D., Visschedijk, A.J.H. \& Schaap, M., Brake wear from vehicles as an important source of diffuse copper pollution. Water Science and Technology, 56(1), pp. 223-231, 2007.

[40] John, K., Karnae, S., Crist, K., Kim, M., John, K. \& Karnae, S., Analysis of trace elements and ions in ambient fine particulate matter at three elementary schools in Ohio. Journal of Air and Waste Management, 57(4), pp. 394-406, 2007. DOI: http://doi.org/10.3155/1047-3289.57.4.394. 